\title{
A súlyos akut légzőszervi szindrómát okozó koronavírus-2 (SARS-CoV-2) orvosilag releváns aspektusai állatokban
}

\author{
Valkó Anna dr. ${ }^{1}$ - Medgyaszai Melinda dr. ${ }^{2}$ \\ ${ }^{1}$ Állatorvostudományi Egyetem, Budapest \\ ${ }^{2}$ Országos Korányi Tbc és Pulmonológiai Intézet, Budapest
}

\begin{abstract}
A mikroszkóp felfedezése óta tudjuk, hogy az egymással szoros közelségben élő egyedeknek nem csupán a látható élőhelyük közös, hanem szemmel nem érzékelhetô mikroorganizmusokat is megosztanak egymással, melyek bizonyos fokban adaptálódtak gazdáikhoz. Az emberek életterének bővülésével és ezzel párhuzamosan az állatok élőhelyének csökkenésével azonban új állatfajok kerülhetnek veszélyes közelségbe, ami következményes mikrobaátadással és az új gazdában a mikroba eltérő viselkedésével járhat. Feltételezhetően ez a jelenség vezetett a súlyos akut légzőszervi szindróma koronavírus-2 (SARS-CoV-2) kialakulásához, mely 2019-ben jelent meg először emberekben, és néhány hónap leforgása alatt milliókat fertőzött meg az egész világon. A pandémia leküzdéséhez és az újabb járványok megelőzéséhez minden lehetséges eszközt fel kell használni, ami együttmúködést kíván a humánorvoslás és az állatgyógyászat, valamint az ökológiai, evolúciós és környezeti tudományok szakemberei között a globális „Egy Egészség” keretében. A közös célok érdekében történő összefogás jegyében a jelen tanulmány állatorvos és humánorvos szerzőpárosa összefoglalja azon ismereteket, amelyek a SARS-CoV-2 vonatkozásában mindkét szakma számára érdemlegesek lehetnek. Bemutatásra kerül a vírus eredete, természetes és mesterséges előfordulása különböző állatfajokban, valamint az állati koronavírusokkal kapcsolatos azon tapasztalatok, amelyek hozzájárulhatnak a SARSCoV-2 múködésének megértéséhez és az ellene való védekezés tökéletesítéséhez.
\end{abstract}

Orv Hetil. 2021; 162(5): 163-170.

Kulcsszavak: SARS-CoV-2, koronavírusok, állatgyógyászat, Egy Egészség

\section{Medically relevant aspects of severe acute respiratory syndrome coronavirus 2 (SARS-CoV-2) in animals}

Since the discovery of the microscope, we have known that individuals living in close proximity to each other share not only their visible habitat, but also invisible microorganisms that have adapted to some degree to their hosts. However, as human habitat expands and, in parallel, animal territory declines, new animal species can come into dangerous proximity, which may result in consequential transmission of microbes and different microbial behaviour in the new host. Presumably, this phenomenon led to the development of the severe acute respiratory syndrome coronavirus 2 (SARS-CoV-2), which first appeared in humans in 2019 and infected millions over the course of a few months worldwide. All possible means must be used to combat the pandemic and prevent further epidemics, which will require cooperation between professionals in human medicine and veterinary medicine as well as in the ecological, evolutionary and environmental sciences, within the framework of the global "One Health". In a spirit of working together for common goals, the authors of this study, a veterinarian and a human physician, summarize the knowledge that may be relevant to both professions for SARS-CoV-2. The origin of the virus, its natural and artificial occurrence in different animal species, and experiences with animal coronaviruses that may contribute to the understanding of the functioning of SARS-CoV-2 and the development of protection against it are presented.

Keywords: SARS-CoV-2, coronaviruses, veterinary medicine, One Health

Valkó A, Medgyaszai M. [Medically relevant aspects of severe acute respiratory syndrome coronavirus 2 (SARS-CoV-2) in animals]. Orv Hetil. 2021; 162(5): 163-170.

(Beérkezett: 2020. november 20.; elfogadva: 2020. december 8.) 


\section{Rövidítések}

ACE2 = (angiotensin-converting enzyme 2) az angiotenzinkonvertáló enzim 2-es típusa; $\mathrm{BCoV}=$ (bovine coronavirus) szarvasmarha-koronavírus; $\mathrm{CCoV}=$ (canine coronavirus) $\mathrm{ku}^{-}$ tya-koronavírus; COVID-19 = (coronavirus disease 2019) koronavírus-betegség 2019; $\mathrm{CRCoV}=$ (canine respiratory coronavirus) kutya légzőszervi koronavírusa; $\mathrm{FCoV}=$ (feline coronavirus) macska-koronavírus; $\mathrm{FeCoV}=$ (feline enteric coronavirus) macska enteralis koronavírus; FIPV $=($ feline infectious peritonitis virus) macska fertőző hashártyagyulladás vírus; $\mathrm{HCoV}=$ (human coronavirus) humán koronavírus; IBV = (infectious bronchitis virus) fertőző bronchitis vírusa; $\mathrm{kb}=$ kilobázis; MERS-CoV = (Middle East respiratory syndrome coronavirus) közel-keleti légúti szindróma koronavírus; NÉBIH = Nemzeti Élelmiszerlánc-biztonsági Hivatal; NHP $=$ (nonhuman primates) emberen kívüli fóemlősök; OIE = (Office International des Epizooties) Állategészségügyi Világszervezet; $\mathrm{PDCoV}=$ (porcine deltacoronavirus) sertés-deltakoronavírus; $\mathrm{PEDV}=$ (porcine epidemic diarrhoea virus) sertések járványos hasmenésének vírusa; PHEV = (porcine haemagglutinating encephalomyelitis virus) malacok agy- és gerincvelö-gyulladását okozó hemagglutináló vírus; $\mathrm{PRCV}=$ (porcine respiratory coronavirus) sertés légzőszervi koronavírusa; RNS = ribonukleinsav; SADS- $\mathrm{CoV}=$ (swine acute diarrhea syndrome coronavirus) sertés akut hasmenés szindróma koronavírus; SARS$\mathrm{CoV}-2=($ severe acute respiratory syndrome coronavirus 2$)$ súlyos akut légzőszervi szindróma koronavírus-2; TGEV = (transmissible gastroenteritis virus) a transzmisszibilis gastroenteritis vírusa; $\mathrm{WHO}=$ (World Health Organization $)$ Egészségügyi Világszervezet

Az „Egy Egészség” szemlélet lényege egy olyan transzdiszciplináris együttmúködésre való törekvés, amely ötvözi az emberiség, az állatvilág és az ökoszisztéma egészségének megőrzésére irányuló törekvéseket [1]. A koncepció szükségességét egyértelműen alátámasztja a súlyos akut légzőszervi szindróma koronavírus-2 (SARSCoV-2) megjelenése, mely mind az egyes fajokra szakosodott tudományterületek, mind az országok határait figyelmen kívül hagyva az egész világra kiterjedő pandémiát okozott. Közleményünk célja, hogy az „Egy Egészség” jegyében összefoglaljuk azon állatgyógyászati ismereteket, amelyek az orvosi szakma számára is informatívak lehetnek.

\section{Fajok közötti átvitel}

A koronavírusok nagy méretű $(26,4-31,7 \mathrm{~kb})$, pozitív irányultságú RNS-genommal, burokkal rendelkező vírusok [2]. Mutációk és rekombinációk rendkívül gyakran fordulhatnak elő egy ekkora genom sokszorosítása, azaz a vírus replikációja során, mely egyaránt magyarázhatja a koronavírusok változékonyságát, a különböző szervek iránti tropizmusukat és új fajokban való megjelenésüket. Népes családjuk tagjai az emlősöket fertőző $A l p h a-$ és Beta-, valamint a főként madarakat fertőző Gamma- és Deltacoronavirus nemzetségbe sorolhatók. A humán vagy állategészségügyi szempontból jelentősebb vírusokat az 1. táblázat foglalja össze.

A kórokozót a természetben fenntartó, azaz rezervoár fajok denevérek, madarak és rágcsálók lehetnek, melyekrôl a vírus átkerülhet egy új fajra [3]. Erre az ún. „spillover” jelenségre számos példát szolgáltatnak az állatok

1. táblázat |Az egészségügyi szempontból jelentős koronavírusok

\begin{tabular}{|c|c|c|c|}
\hline $\begin{array}{l}\text { Vírus- } \\
\text { nemzetség }\end{array}$ & Érintett faj & Vírus & Betegség/érintett szerv \\
\hline \multirow{8}{*}{$\begin{array}{l}\text { Alphacorona- } \\
\text { virus }\end{array}$} & \multirow{2}{*}{ Ember } & $\mathrm{HCoV}-229 \mathrm{E}$ & Közönséges nátha \\
\hline & & HCoV-NL63 & Közönséges nátha \\
\hline & Macska & FCoV & $\begin{array}{l}\text { Emésztőszervi vagy } \\
\text { fertőző hashártya- } \\
\text { gyulladás }\end{array}$ \\
\hline & Kutya & $\mathrm{CCoV}$ & Emésztőszervi \\
\hline & \multirow[t]{4}{*}{ Sertés } & TGEV & $\begin{array}{l}\text { Transzmisszibilis } \\
\text { gastroenteritis }\end{array}$ \\
\hline & & PRCV & Légzőszervi \\
\hline & & PEDV & $\begin{array}{l}\text { Sertések járványos } \\
\text { hasmenése }\end{array}$ \\
\hline & & SADS-CoV & $\begin{array}{l}\text { Sertés akut hasmenés } \\
\text { szindróma }\end{array}$ \\
\hline \multirow{10}{*}{$\begin{array}{l}\text { Betacorona- } \\
\text { virus }\end{array}$} & \multirow[t]{5}{*}{ Ember } & $\mathrm{HCoV}-\mathrm{OC} 43$ & Közönséges nátha \\
\hline & & HCoV-HKUl & Légzőszervi \\
\hline & & MERS-CoV & $\begin{array}{l}\text { Közel-keleti légúti } \\
\text { szindróma }\end{array}$ \\
\hline & & SARS-CoV & $\begin{array}{l}\text { Súlyos akut légzőszervi } \\
\text { szindróma }\end{array}$ \\
\hline & & SARS-CoV-2 & $\begin{array}{l}\text { Koronavírus-betegség } \\
2019\end{array}$ \\
\hline & Kutya & $\mathrm{CRCoV}$ & Légzőszervi \\
\hline & $\begin{array}{l}\text { Szarvas- } \\
\text { marha }\end{array}$ & $\mathrm{BCoV}$ & $\begin{array}{l}\text { Emésztő- vagy } \\
\text { légzőszervi }\end{array}$ \\
\hline & Ló & $\mathrm{ECoV}$ & Emésztőszervi \\
\hline & Sertés & PHEV & $\begin{array}{l}\text { Agy- és gerincvelö- } \\
\text { gyulladás }\end{array}$ \\
\hline & Egér & MHV & $\begin{array}{l}\text { Bél-, máj- vagy } \\
\text { agyvelőgyulladás }\end{array}$ \\
\hline \multirow[t]{2}{*}{$\begin{array}{l}\text { Gamma- } \\
\text { coronavirus }\end{array}$} & Házityúk & IBV & $\begin{array}{l}\text { Csirkék fertőzó } \\
\text { bronchitise }\end{array}$ \\
\hline & Pulyka & $\mathrm{TCoV}$ & Emésztőszervi \\
\hline $\begin{array}{l}\text { Deltacorona- } \\
\text { virus }\end{array}$ & Sertés & PDCoV & Emésztőszervi \\
\hline
\end{tabular}

$\mathrm{BCoV}=$ szarvasmarha-koronavírus; $\mathrm{CCoV}=$ kutya-koronavírus; $\mathrm{CRCoV}=$ kutya légzószervi koronavírusa; $\mathrm{ECoV}=$ lókoronavírus; $\mathrm{FCoV}=$ macska-koronavírus; $\mathrm{HCoV}=$ humán koronavírus; $\mathrm{IBV}=$ fertőző bronchitis vírusa; MERS-CoV = közel-keleti légúti szindróma koronavírus; $\mathrm{MHV}$ = egér-hepatitisvírus; $\mathrm{PDCoV}$ = sertés-deltakoronavírus; PEDV = sertések járványos hasmenésének vírusa; $\mathrm{PHEV}=$ malacok agy- és gerincvelő-gyulladását okozó hemagglutináló vírus; PRCV = sertés légzőszervi koronavírusa; SADS-CoV = sertés akut hasmenés szindróma koronavírus; SARS-CoV = súlyos akut légzőszervi szindróma koronavírus; $\mathrm{TCoV}=$ pulyka-koronavírus; $\mathrm{TGEV}=\mathrm{a}$ transzmisszibilis gastroenteritis vírusa 
koronavírusai, a legjellemzőbb módon talán a sertések esetében: a transzmisszibilis gastroenteritis vírusa (TGEV) kutya-koronavírus (CCoV), a sertések járványos hasmenésének vírusa (PEDV) denevér-, a sertésdeltakoronavírus (PDCoV) madáreredetû lehet $[4,5]$, a malacok agy- és gerincvelő-gyulladását okozó hemagglutináló vírus (PHEV) pedig szintén denevérektől származhat a szarvasmarha-koronavírus (BCoV) közvetítésével [6]. A 2018-ban újonnan azonosított sertés akut hasmenés szindróma koronavírus (SADS-CoV) ugyancsak denevérektől származhat, mégpedig olyan denevérfajoktól, amelyek humán koronavírusok rezervoárjai is [7].

A fajok közötti határok áttörése azt is jelentheti, hogy a kórokozó az állatokról az emberre terjed át, mely jelenség régóta ismert például az influenzavírusok esetén [8], de új kutatások a korábban ismeretlen eredet hátterében is állatfajokat azonosíthatnak, ahogyan erre a rózsahimlő tanulmányozása rávilágított [9]. Szekvenciaanalízisek alapján minden humán koronavírus $(\mathrm{HCoV})$ állati eredetü; a fertőzés kiindulási pontja általában egy denevérvagy rágcsálófaj, jellemzően köztes szereplők beiktatásával.

A legtöbbször enyhe légzőszervi megbetegedést okozó endémiás humán koronavírusok közül a HCoV-229E és a $\mathrm{HCoV}$-NL63 eredete a denevérekre, míg a $\mathrm{HCoV}$ OC43 és a $\mathrm{HCoV}-\mathrm{HKUl}$ rágcsálókra vezethető vissza [6]. A HCoV-229E esetén viszont a háziállatként tartott egypúpú tevék (Camelus dromedarius) közvetíthették a vírust a denevérről az emberre, a $\mathrm{HCoV}-\mathrm{OC} 43$ pedig a szarvasmarhához való adaptáció után kerülhetett át emberre és sertésre. Ugyanakkor, a HCoV-NL63 és a HCoV-HKUl késóbb került felfedezésre, így nem kizárt, hogy esetükben is jelen volt köztigazda, melyet eddig még nem sikerült azonosítani.

Az utóbbi két vírus felfedezését a koronavírusok kutatására irányuló kiemelt figyelem hozta el, melyet a súlyos akut légzőszervi szindróma koronavírus (SARS-CoV) 2002-2003. évi megjelenése indukált. A SARS-CoV volt az első, erősen patogén humán koronavírus, melyet 2012-ben a közel-keleti légúti szindróma koronavírus (MERS-CoV) megjelenése követett [10]. A fertőzés eredeti forrásaként mindkét kórokozó esetében különbözó denevérfajokat azonosítottak, míg a köztigazdák a SARS-CoV kialakulásában a cibetmacskafélék (Viverridae), a MERS-CoV átvitelében pedig az egypúpú tevék (Camelus dromedarius) lehettek.

A SARS-CoV gyors eltünését követően a koronavírusok monitorozása és a preventív intézkedések tervezése s fóként finanszírozása alábbhagyott, annak ellenére, hogy a szignifikáns mortalitással járó humán koronavírusok, SARS-szerú vírusok és a SADS-CoV megjelenése miatt számos kutató figyelmeztetett a lehetséges veszélyre, melyet az alfa- és/vagy béta-koronavírusokat hordozó több mint száz denevérfajjal való szoros együttélés jelenthet [11]. A kínai Wuhan városból súlyos légzőszervi megbetegedésról számoltak be 2019 decemberében, melynek hátterében hamarosan egy új koronavírust, a későbbiekben SARS-CoV-2 elnevezésű vírust azonosították [12]. E sorok írásakor a SARS-CoV-2 által okozott koronavírus-betegség 2019 (COVID-19) jelentett eseteit nyomon követő online felület több mint 56 millió fertőzöttről és 1,3 millió halálesetről számol be [13]. A kutatók többsége megegyezik abban, hogy a pandémiát okozó SARS-CoV-2 a többi humán koronavírushoz hasonlóan állati eredetú, amit a korábban említett állatikoronavírus-példák is alátámasztanak. Egy erre irányuló új tanulmányban 1238 denevér szekvenciavizsgálata alapján a SARS-CoV-2 a legközelibb rokonságot a patkósdenevérek (Rhinolophidae) koronavírusainak egy csoportjával mutatta [14]. Ugyanakkor az eddig talált denevér-koronavírusok egyike sem mutat elég nagyfokú hasonlóságot a SARS-CoV-2-vel a denevér és ember közötti közvetlen transzmisszió igazolásához, így szükséges a köztigazda azonosítása is. A pandémia kezdetén a jávai tobzoska (Manis javanica) merült fel közvetítőként, azonban a vizsgálat során fertőzöttnek bizonyult állatok esetében a vadonban történő akvirációnál valószínúbbnek tûnik a szállítás során történő fertőződés [15]. Az egyik legújabb, még felülvizsgálat alatt álló közlemény a nyestkutyát (Nyctereutes procyonoides) azonosította lehetséges köztigazdaként, mert a kísérleti állatokat sikeresen fertőzték a SARS-CoV-2-vel, és a fertőzött állatok továbbadták a kórokozót a velük egy ketrecben lévő, korábban vírusmentes társaiknak [16]. Ugyanakkor a pandémia eredetének tisztázására további kutatásokra van szükség, elsősorban a vadvilág vizsgálatára fókuszálva, beleértve vadászterületeket, raktárakat, farmokat és piacokat, hiszen az első COVID-19-esetek egy élő állatokkal is kereskedő piachoz köthetők. Pontos válaszokat így csak akkor várhatunk, ha az összes potenciális vad- és háziállat tesztelése megtörténik a kereskedelem teljes vertikumában, ami az Egészségügyi Világszervezet (WHO) által kezdeményezett nagyszabású nemzetközi összefogás révén valósulhat meg [17].

\section{Zoonosis és reverz zoonosis}

Ha a SARS-CoV-2 állati eredetú, akkor a COVID-19 zoonosis? A korrekt válaszhoz először tisztázni kell a zoonosis fogalmát, mely a WHO alapján „a gerinces állatok és az ember között természetes úton átadott összes betegség és fertőzés" [18]. Korábban elkülönítették az anthropozoonosis (állatról emberre terjedő betegség) és a zooanthroponosis (emberről állatra terjedő betegség) fogalmát is, de ezeket sajnos a szakemberek is gyakran fordítva használták, ezért határozott egy erre szakosodott bizottság e kifejezések elhagyásáról és a zoonosis megnevezés használatáról mindkét irányú terjedés leírására. Az egyértelmúség kedvéért a továbbiakban a napjainkban elterjedtebb reverz zoonosis kifejezést használjuk az emberról állatra terjedő betegségre vagy fertőzésre, és zoonosison csak az állatról emberre történő átvitelt értjük. 
Zoonosisról tehát akkor beszélhetünk, ha az ember általában állatoktól fertőződhet, és az emberek közötti átvitel ritka. Klasszikusan ilyen betegség például a veszettség. Így a SARS-CoV-2 esetén csak zoonoticus eredetról lehet szó, zoonosisról nem.

Ne gondoljuk azonban, hogy a fertőzési út kizárólag egyirányú lehet, hiszen példának okáért az influenzavírusok, illetve a meticillinrezisztens Staphylococcus aureus kapcsán is megfigyelték [19], hogy az emberek váltak biológiai kockázati tényezővé az állatok számára, s ez a jelenség - ahogy késóbb látni fogjuk - akár vissza is üthet az emberiségre. A SARS-CoV-2 vonatkozásában az állat és ember közötti, természetes úton történt átvitelt az 1 . ábra szemlélteti.

Az egyik első leírás reverz zoonosisról a SARS-CoV-2 kapcsán egy állatkertből származott, ahol 2020 márciusában négy tigris és három oroszlán enyhe légzőszervi tüneteket mutatott, epidemiológiai és genetikai vizsgálatok pedig bizonyították, hogy a vírus fertőzött állatkerti dolgozóról vagy dolgozókról került át a tigrisekre [20]. Ugyanezt az oroszlánok esetében nem sikerült egyértelmúen megállapítani, és az sem tisztázott, hogy közvetlen vagy közvetett módon (ragályfogó tárggyal) történt az átvitel, valamint a nagymacskák terjeszthették-e egymás között a betegséget.
A népesség nagyobb részének azonban sokkal fontosabb a háziállatok fogékonysága, mellyel kapcsolatban egy átfogó tanulmány megállapította, hogy a SARSCoV-2 gyengén replikálódik kutyákban, sertésekben, csirkékben és kacsákban, viszont a macskák és a vadászgörények fogékonyabbak a fertőzésre [21]. Macskák között ráadásul bizonyítottnak túnik a levegőn keresztüli terjedés is, ám az ezt alátámasztó vizsgálat során rendkívül magas dózisú vírussal fertőzték a kísérleti állatokat, mely nem feltétlenül felel meg a természetes körülményeknek. Az utóbbit jobban szemlélteti az a tanulmány, mely bizonyított vagy feltételezett SARS-CoV-2-pozitív tulajdonosoknak klinikai tüneteket (letargia, hasmenés, hányás, köhögés és egyéb légzőszervi tünetek) mutató állatait vizsgálta a vírus örökítőanyagának, valamint a fertőzésre adott immunválasz eredményeként megjelenő ellenanyagoknak a kimutatásával [22]. A vizsgált 11 kutya mindegyike negatív volt mindkét módszerrel, míg a 22 macska közül egy esetben sikerült kimutatni a vírust és ellenanyagokat is. A kutyák és a macskafélék fogékonysága közötti eltérést az angiotenzinkonvertáló enzim 2-es típusának (ACE2) különbségei magyarázhatják, mely sejtfelszíni receptorként szolgál a SARS-CoV-2-fertőzés során, a vírus ezen keresztül képes megfertőzni a sejteket [23]. Számítógépes analízis alapján a macska-

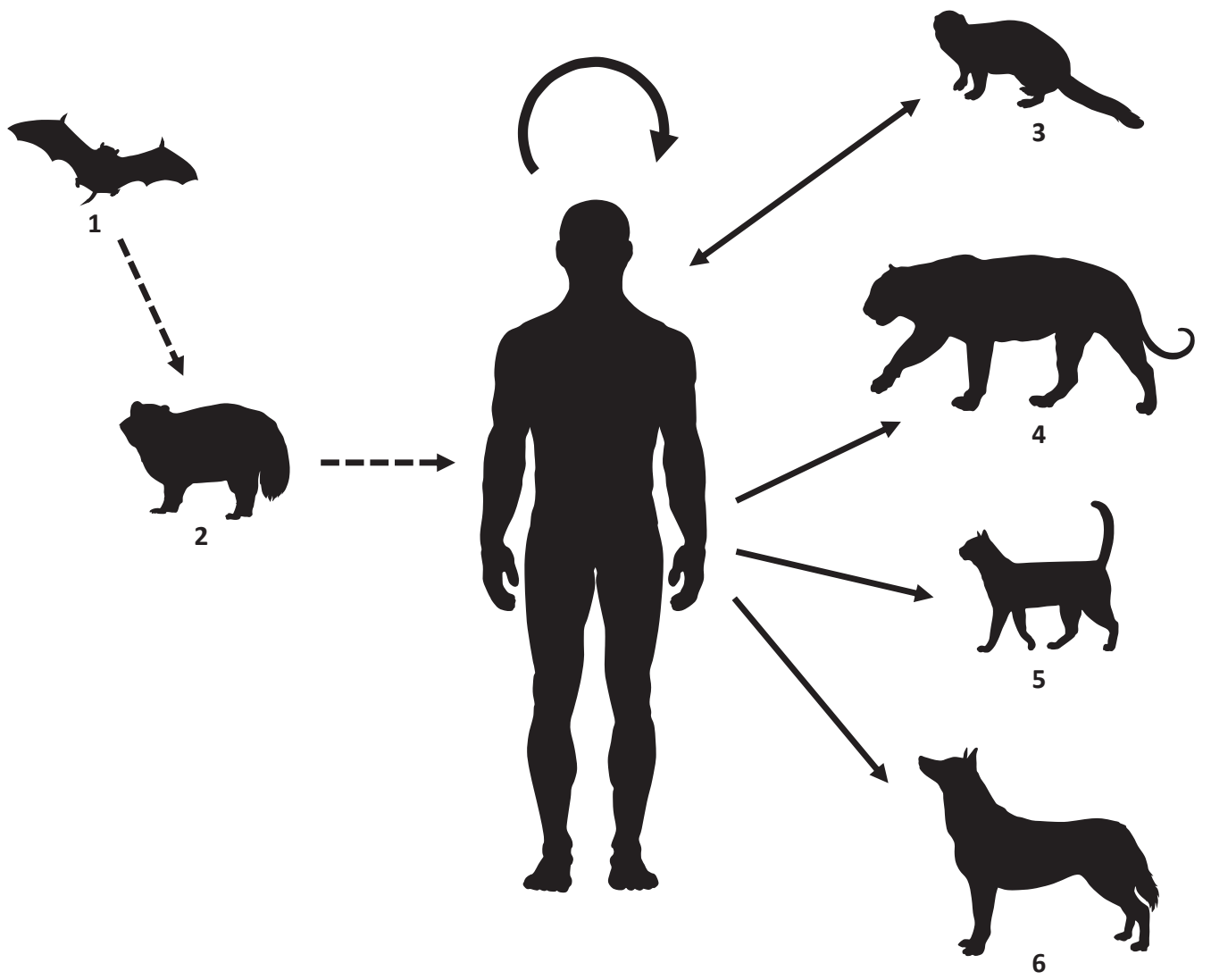

\begin{tabular}{l|l} 
1. ábra & $\begin{array}{l}\text { A SARS-CoV-2 lehetséges transzmissziós útvonalai a természetben (a szerzók saját munkája }[14,16,20,22,27] \text { alapján) } \\
1=\text { patkósdenevérek; } 2=\text { nyestkutya; } 3=\text { nyérc; } 4=\text { tigris; } 5=\text { macska; } 6=\text { kutya } \\
\text { SARS-CoV- } 2=\text { súlyos akut légzószervi szindróma koronavírus- } 2\end{array}$
\end{tabular} 
ACE2 jobban hasonlít a humán ACE2-re, ami szintén arra enged következtetni, hogy a macska fogékonyabb lehet a SARS-CoV-2-fertőzésre a kutyánál, enyhe tüneteket mutathat, és ürítheti is a vírust [24]. Emiatt, bár az átvitel kockázata alacsony, tanácsos a COVID-19-betegeknek limitálni a háziállatukkal való érintkezést (az állatorvosok többsége egyébiránt sem javasolja a kis kedvencek csókolgatását). Bizonyíték nincs arra vonatkozóan, hogy a macska továbbíthatná a fertőzést az emberre, ezért a tulajdonosoknak nem kellene lemondaniuk társállataikról a betegségtől való félelem miatt.

Az állatkerti állatok, kutyák és macskák között egyedi esetekról számoltak be, holland nyérc- (Neovison vison) farmokon viszont több, SARS-CoV-2 okozta járványkitörés is előfordult [25]. Az előzőekben említett háziállatoktól eltérően azonban a nyércek között már súlyos megbetegedést is megfigyeltek, mely az érintett egyedek pusztulásával járt. Ezen állatok kórbonctani vizsgálata során a COVID-19 következtében elhunyt betegek tüdőelváltozásaihoz hasonló interstitialis pneumoniát és diffúz alveolaris károsodást figyeltek meg, valamint immunhisztokémiai vizsgálattal igazolták a tüdőszövetben a SARS-CoV-2 jelenlétét $[25,26]$. A szigorú higiéniai elóírások és szállítási korlátozások ellenére egyre több nyércfarmon jelent meg a betegség; egy preprint tanulmány júniusig 16 farmot vont be egy kontaktkutatáson és különböző diagnosztikai módszereken alapuló vizsgálatba [27]. Felmerült egy erősebben patogén vírusváltozat megjelenése is a nyércekben, de nem találtak ugyanolyan mutációt minden vizsgált nyércmintában, inkább a farmokon lévő nagy populáció vezethetett a gyors terjedéshez. Szekvenciaelemzések alapján a nyércek a dolgozóktól fertőződhettek meg, viszont korábban SARSCoV-2-negatív munkások azt követően mutatták a COVID-19 tüneteit, és váltak pozitívvá, hogy az adott farmon a nyércek közt megjelent a betegség. Ebben az esetben már valóban erósen megalapozott a zoonosis előfordulásának gyanúja, mely következtében a holland kormány bejelentette az ország összes nyércfarmjának felszámolását 2021 márciusáig, az emberek egészségének védelme érdekében (https://www.hsi.org/newsmedia/dutch-mink-fur-farms-to-be-permanently-closed/). A fogságból kiszabaduló nyércek keveredhetnek vadon élő társaikkal, bár a dús, változatos színű prémekre irányuló tenyésztés miatt külsőre és genetikailag is eltérnek egymástól [28]. A vadon élő nyércek SARSCoV-2-re vonatkozó fogékonysága így hasonló lehet a farmokon tartott nyércekéhez, de tekintettel a vadállatok közti zsúfoltság hiányára, valamint az ember és nyérc találkozásának körülményeire (ritka, és általában a nyérc elmenekülésével vagy pusztulásával jár), ezek az állatok valószínúleg elhanyagolható veszélyt jelentenek a COVID-19 előfordulása szempontjából.

Nem kizárt, hogy további állatfajokban mutassák ki a SARS-CoV-2 jelenlétét, mely esetlegesen kockázatot jelenthet az ember számára is, ezért az állatok természetes úton előforduló fertőződésének monitorozása érdeké- ben a bejelentett esetekről az Állategészségügyi Világszervezet (OIE) nyilvántartást vezet (https://www.oie. int/en/scientific-expertise/specific-information-and-recommendations/questions-and-answers-on-2019novelcoronavirus/events-in-animals/), valamint aktuális információkat biztosít a SARS-CoV-2 vonatkozásairól az állatokkal, illetve állati termékekkel kapcsolatban. Hasonló ismeretanyag magyar nyelven a Nemzeti Élelmiszerlánc-biztonsági Hivatal (NÉBIH) honlapján (https://portal.nebih.gov.hu/) „A koronavírus állategészségügyi vonatkozásai” címen érhető el.

\section{Állati modellek a SARS-CoV-2 vizsgálatához}

A COVID-19 kórfejlődésének vizsgálatához, valamint a betegség kezelését, illetve megelőzését szolgáló gyógyszerek és vakcinák kifejlesztéséhez elengedhetetlenek az állati modellek, ezért az egyes fajok fogékonyságának feltérképezése a megfelelő kísérleti állat meghatározásában is szerepet játszik. Az emlősállatok és az ember között immunológiailag számos hasonlóságot találunk, mind a veleszületett, mind az adaptív immunrendszer múködésének tekintetében. Ennélfogva az intracelluláris kórokozók elleni immunválasz alapjai is megegyezhetnek, ugyanakkor számottevő különbségek adódhatnak az adott patogén tulajdonságainak, valamint az egyes fajok specifikus fehérjéinek eltéréseiből.

Az ACE2 ebben az esetben is kulcsfontosságú; például a leggyakrabban használt egér- (Mus musculus) modell esetén a vad típusú egerek ellenállnak a SARS-CoV-2fertőzésnek eltérő receptoruk miatt, ezért új egértörzsek kialakítása szükséges a kutatásokhoz [29]. Az egyik lehetséges mód a transzgenikus egerek létrehozása, melyekben az egér-ACE2-t részben vagy teljesen humán eredetü ACE2-re cserélik - ez már a 2000-es évek elején a SARS-CoV-kutatások kapcsán is felmerült. Akkor hozták létre például a K18-hACE2 egérvonalat, mely a SARS-CoV kórfejlődésének modellezésére kevésbé bizonyult alkalmasnak, mert - feltehetóen a humán ACE2 nagymértékű idegrendszeri kifejeződése miatt - a fertőzés minden esetben az állatok pusztulását okozta [30]. Ugyanez az egérvonal viszont ígéretesnek tûnik a COVID-19 patogenezisének és a terápiás beavatkozási lehetőségeknek a vizsgálatára: a kísérletek során az egerekben az enyhétől a súlyoson át a letálisig terjedően sikerült kiváltani a betegséget a SARS-CoV-2 fertőző dózisának módosításával, valamint megfigyelték az anosmia, azaz a szaglás elvesztésének jelenségét is, mely az emberekhez hasonlóan a nóivarú egyedekben volt általánosabb [31]. Ugyanakkor ezeknek az egereknek a létrehozása meglehetősen időigényes: hónapok telnek el, mire bevonhatók lesznek egy kísérletbe.

Az ACE2 fehérje elemzése révén egy másik kis testű rágcsáló került a kutatók figyelmének középpontjába, mégpedig a szíriai aranyhörcsög (Mesocricetus auratus), melyet korábban már több légzőszervi kórkép vizsgála- 
tára is használtak, beleértve a SARS-CoV okozta megbetegedést is [32]. Az egyik első tanulmány alapján az aranyhörcsögök az enyhe és mérsékelten súlyos COVID-19 modellezésére lehetnek alkalmasak, melyet kontakt és aeroszol útján közvetíthetnek is egymás között [33]. Újabb kutatások már vizsgálták egyes terápiás beavatkozások (rekonvaleszcens, azaz gyógyulófélben lévő betegból vett savó, hidroxiklorokin és favipiravir), illetve vakcinák múködését is ezekben az állatokban [32]. Modellként való felhasználásukat sajnálatos módon korlátozza, hogy az egerekhez képest egyelöre kevesebb eszköz áll rendelkezésre vizsgálatukhoz, elsősorban az immunológiai válaszreakciók terén.

A kis testû ragadozók közül a vadászgörényt (Mustela putorius furo) alkalmazták már modellként, elsősorban az influenzavírusok vizsgálatára, ezeknek az állatoknak a tartása viszont bonyolultabb a rágcsálókhoz képest, legnagyobb hátrányuk pedig a fajspecifikus reagensek korlátozott elérhetősége [34]. A SARS-CoV-2-fertőzés okozta felső légúti elváltozások és a vonatkozó terápiás beavatkozások - akár a nyálkahártya-immunitás kialakításának vizsgálatára - viszont meglehetős potenciállal bírnak, így várhatóan ki fog bővülni a vadászgörényekkel végzett kutatások eszköztára [21, 34].

Genetikai és anatómiai rokonságunkból fakadóan az emberen kívüli fóemlősök (NHP) a legjobb állati modellek a humán betegségek vizsgálatára, közülük pedig az ACE2-receptor-hasonlóság alapján a rézuszmajmok (Macaca mulatta) tüntek a legideálisabbnak a SARSCoV-2 vonatkozásában [35]. Ugyanakkor a SARS-CoV2 -fertőzés egyetlen vizsgált NHP-fajban sem, így a rézuszmajmokban sem váltott ki súlyos klinikai tünetekben megnyilvánuló betegséget, annak ellenére, hogy az emberekhez hasonlóan az idősebb majmokban súlyosabb interstitialis tüdőgyulladás alakult ki a fiatalokhoz képest $[32,36]$. Következésképp az NHP-modellek - fenntartásokkal kezelve, de - továbbra is elengedhetetlenül szükségesek, elsősorban a vakcinák hatékonyságának teszteléséhez, mellyel kapcsolatban fóként az alsó légutak védelmére irányulóan biztató eredményekről számoltak be.

\section{Tanulságok az állatvilágból}

Az állatorvos-tudományban a koronavírusokkal szerzett tapasztalatok segíthetnek a humán vírusok okozta megbetegedések elleni küzdelemben a kórokozók változékonyságának, az ellenük kialakult immunválasznak és az aktív védekezésnek a tekintetében.

Genetikai szempontból az összehasonlítást az ugyanazon nemzetségbe tartozó vírusokkal érdemes kezdeni, melyek közül a kutya légzőszervi koronavírusa (CRCoV) túnik ideális választásnak, megegyező szervtropizmusa miatt [37]. Ugyanakkor a CRCoV a SARS-CoV-2-vel szemben önállóan legfeljebb minimális tüneteket indukál; egyéb kórokozókkal együttesen alakíthatja ki a kennelköhögés néven ismert, általában menhelyeken vagy versenyeken összezsúfolódott kutyák közt előforduló, komplex légzőszervi betegséget [38]. Genetikailag pedig inkább a HCoV-OC43-mal és a BCoV-vel mutat szoros rokonságot. Így a COVID-19 modellezésére a CRCoV kevésbé alkalmas; a SARS-CoV-2 vonatkozásában inkább szerológiai szempontból lehet érdekes, hogy az enyhe légzőszervi megbetegedést okozó $\mathrm{HCoV}$ OC43-mal való hasonlósága miatt képes lehet-e keresztreakciót adni, mely zavarhatja a SARS-CoV-2-specifikus ellenanyagok kimutatását, vagy esetleg bizonyos fokú védelmet nyújthat a megbetegedés ellen [39].

Hasonlóképpen az antitestalapú immunválasz vonatkozásában lehet informatív egy szarvasmarhatelepeken dolgozók körében végzett felmérés a $\mathrm{BCoV}$ kapcsán, mely kettős szövettropizmusa és életkorfüggő kórképek tekintetében is precedensértékú lehet. A $\mathrm{BCoV}$ ugyanis az emésztô- és légzőszervek iránt is fogékony, néhány hetes borjakban hasmenést, felnőtt állatokban vérzéses jellegú, ún. téli hasmenést, néhány hónapos borjakban, illetve fiatal felnőttekben pedig önállóan enyhe, társfertőzésekkel együtt súlyosabb légzőszervi megbetegedést okozhat [40]. Az utóbbi esetén a kórokozók mellett jelentős szerepe van a szállítási stressznek, mely például a különböző telepekről hosszasabb szállítmányozást követően hizlaldába kerülő állatoknál figyelhetô meg, és az immunrendszer gyengítése révén fokozhatja a betegségre való fogékonyságot. Ez a jelenség párhuzamba állítható a hosszú repülőutak során az egymástól távoli helyekről származó, de szoros közelségbe kerülő embereknél kialakuló utazási stresszel, mely a SARS-CoV-2 terjedésében is közrejátszhat, bár az akut stressz során a nyál besűrúsödése miatt a transzmisszió csökkenhet [41].

Genetikailag távolabb áll a SARS-CoV-2-től, de hasonló szövettropizmusa, valamint egy frappáns „vírusmegoldás" miatt említést érdemel a sertés légzőszervi koronavírusa (PRCV). A PRCV a súlyos hasmenést okozó TGEV természetes úton kialakult deletiós mutánsa, mely a TGEV-vel szemben legfeljebb korlátozottan replikálódik az emésztőcsatornában, és a sertés komplex légzőszervi megbetegedéséhez járulhat hozzá [40]. A „szerencsés” mutációt követően az elterjedő PRCV kvázi visszaszorította a TGEV által kiváltott betegség előfordulását, feltehetóen a PRCV által indukált, de TGEV ellen is hatásos immunválasz kialakulása miatt. Ennek a keresztvédettségnek a mintájára a SARS-CoV-2 elleni immunitás kialakítása érdekében megfontolandó olyan mesterségesen előállított vírusváltozatok vizsgálata, amelyek legfeljebb enyhe tüneteket okozhatnak akár eltérő szövetben, de a nyálkahártya-immunitás révén hatékony védelmet biztosítanak a kórokozóval szemben.

A macska koronavírusa ( $\mathrm{FCoV})$ a koronavírusok változékonyságának jelentőségét és az ellenük való védekezés nehézségeit egyaránt szemlélteti. Az FCoV-nak két, genetikailag nem igazán elkülöníthető változata van: a macska enteralis koronavírusának is nevezett $(\mathrm{FeCoV})$ avirulens biotípus, és a magasan patogén biotípus, a macska fertőző hashártyagyulladás vírus (FIPV), mely az 
immunrendszer érintettségével járó fatális kórképet idéz elő [42]. Az FeCoV előfordulása igen gyakori, és legfeljebb enyhe hasmenést, esetleg kismacskákban légzőszervi tüneteket okoz, a fertőzött állatok nagyjából 5\%-ában viszont a vékonybél hámsejtjeiben olyan mutációk zajlanak le a vírusban, amelyek hatására képessé válik replikálódni a veleszületett immunrendszerbe tartozó makrofágokban és monocytákban. Ez a változás kulcsfontosságúnak túnik a FIPV kialakulásában, bár máig nem tisztázott pontosan, mely gének érintettek ezekben a mutációkban, illetve milyen szerepe van a fogékonyság öröklődésének és a környezetnek [43]. A FIPV okozta betegség kezelésére több antivirális készítménnyel is kísérleteztek, melyek közül a GS-441524-nukleozid-analóggal végzett többszöri kezelés hatékonynak bizonyult a kezelt állatok többségében $(25 / 26)$, a betegség megelőzésében viszont az évtizedek óta tartó kísérletezés ellenére a forgalomban lévő egyetlen vakcina esetén sem értek el konzisztens kísérleti eredményeket [44, 45]. Jelenlegi ismereteink szerint a SARS-CoV-2 is képes replikálódni a makrofágokban, ami hozzájárulhat az immunrendszer diszfunkcionális múködéséhez és a következményes súlyos COVID-19 kialakulásához [46]. Így a macska példáját követve el lehet kezdeni kísérletezni antivirális szerekkel való terápia alkalmazásával, ahogyan az a remdezivir (GS-5734) esetében sikeresen történt [47], ugyanakkor a FIPV megelőzésére tett, számos kudarccal végződő kutatás egyúttal előrevetíti a vakcinafejlesztés nehézségeit is.

$\mathrm{Az}$ állatok koronavírusai elleni vakcinák tekintetében az elsők között felfedezett, jelentős gazdasági veszteségeket okozó, a csirkék fertőző bronchitisének vírusa (IBV) kapcsán rendelkezünk a legtöbb ismerettel [48]. Az IBV elleni védelem meglehetősen rövid ideig tart, általában több genotípusú vírus kombinációját tartalmazó, különböző típusú vakcinák ismételt alkalmazása vezethet a hatékony megelőzéshez. A SARS-CoV-2 esetén egyelơre számos ismeretlen tényezôvel állunk szemben a különböző vakcinák fejlesztésében, de például az állatok koronavírusai elleni vakcinákhoz hasonlóan úgy tünik, kétszeres dózisra lesz szükség egy adott oltóanyagból a sikeres védekezéshez [49].

\section{Következtetés}

Nem kérdéses, hogy a SARS-CoV-2-pandémia és annak leküzdése kihívást jelent az egész emberiség számára. Az állatok koronavírusairól szerzett ismeretanyag korlátozottan vonatkoztatható az emberek kórokozóira, mégis hasznos támpontokat nyújthatnak a vírusok múködésének megértéséhez, valamint biztonságos és hatékony antivirális szerek, illetve vakcinák kifejlesztéséhez, melyek segítségével optimistább jövőképet vetíthetünk magunk elé a COVID-19 felszámolásában [50].

Az elmúlt két évtizedben a SARS-CoV, a MERS-CoV, majd a SARS-CoV-2 jutott át az állatokról az emberekre, ami intő jelként szolgál arra nézvést, hogy milyen követ- kezményekkel számolhatunk, ha nem változtatunk a környezethez való viszonyunkon. Egy újabb világjárvány elkerülése érdekében elengedhetetlen az állatvilág monitorozása, különösen tekintettel azon vadállatokra, amelyek zsugorodó életterük peremén szoros közelségbe kerültek az emberekkel. Változásokat hozni és fenntartható együttélést kialakítani az élővilág teljes közösségében pedig csak az „Egy Egészség” szemléletével, közös összefogással lehetséges.

Anyagi támogatás: A közlemény megírása és a kapcsolódó kutatómunka anyagi támogatásban nem részesült.

Szerzői munkamegosztás: Mindkét szerző részt vett az irodalomkutatásban és a publikáció szövegezésében. A cikk végleges változatát mindkét szerző elolvasta és jóváhagyta.

Érdekeltség: A szerzőknek nincsenek érdekeltségeik.

\section{Irodalom}

[1] Destoumieux-Garzón D, Mavingui P, Boetsch G, et al. The One Health concept: 10 years old and a long road ahead. Front Vet Sci. 2018; 5 : 14.

[2] Woo PCY, Huang Y, Lau SK, et al. Coronavirus genomics and bioinformatics analysis. Viruses 2010; 2: 1804-1820.

[3] Decaro N, Martella V, Saif LJ, et al. COVID-19 from veterinary medicine and One Health perspectives: what animal coronaviruses have taught us. Res Vet Sci. 2020; 131: 21-23.

[4] Lorusso A, Decaro N, Schellen P, et al. Gain, preservation, and loss of a group la coronavirus accessory glycoprotein. J Virol. 2008; 82: 10312-10317.

[5] Woo PC, Lau SK, Lam CS, et al. Discovery of seven novel mammalian and avian coronaviruses in the genus Deltacoronavirus supports bat coronaviruses as the gene source of Alphacoronavirus and Betacoronavirus and avian coronaviruses as the gene source of Gammacoronavirus and Deltacoronavirus. J Virol. 2012; 86: 3995-4008.

[6] Corman VM, Muth D, Niemeyer D, et al. Hosts and sources of endemic human coronaviruses. Adv Virus Res. 2018; 100: 163188.

[7] Zhou P, Fan H, Lan T, et al. Fatal swine acute diarrhoea syndrome caused by an HKU2-related coronavirus of bat origin. Nature 2018; 556: 255-258.

[8] Sun H, Xiao Y, Liu J, et al. Prevalent Eurasian avian-like H1N1 swine influenza virus with 2009 pandemic viral genes facilitating human infection. Proc Natl Acad Sci USA 2020; 117: 1720417210.

[9] Bennett AJ, Paskey AC, Ebinger A, et al. Relatives of rubella virus in diverse mammals. Nature 2020; 586: 424-428.

[10] Cui J, Li F, Shi ZL. Origin and evolution of pathogenic coronaviruses. Nat Rev Microbiol. 2019; 17: 181-192.

[11] Morens DM, Breman JG, Calisher CH, et al. The origin of COVID-19 and why it matters. Am J Trop Med Hyg. 2020; 103: 955-959.

[12] Wu F, Zhao S, Yu B, et al. A new coronavirus associated with human respiratory disease in China. Nature 2020; 579: 265269.

[13] Dong E, Du H, Gardner L. An interactive web-based dashboard to track COVID-19 in real time. Lancet Infect Dis. 2020; 20: 533-534. [Erratum: Lancet Infect Dis. 2020; 20(9): e215.] 
[14] Latinne A, Hu B, Olival KJ, et al. Origin and cross-species transmission of bat coronaviruses in China. Nat Comm. 2020; 11 4235.

[15] Lam TT, Jia N, Zhang YW, et al. Identifying SARS-CoV-2-related coronaviruses in Malayan pangolins. Nature 2020; 583: 282285.

[16] Freuling CM, Breithaupt A, Müller T, et al. Susceptibility of raccoon dogs for experimental SARS-CoV-2 infection. Emerg In fect Dis. 2020; 26: 2982-2985

[17] Mallapaty S. Scientists call for pandemic investigations to focus on wildlife trade. Nature 2020; 583: 344.

[18] Hubálek Z. Emerging human infectious diseases: anthroponoses, zoonoses, and sapronoses. Emerg Infect Dis. 2003; 9: 403-404

[19] Messenger AM, Barnes AN, Gray GC. Reverse zoonotic disease transmission (zooanthroponosis): a systematic review of seldomdocumented human biological threats to animals. PLoS ONE 2014; 9: e89055.

[20] McAloose D, Laverack M, Wang L, et al. From people to panthera: natural SARS-CoV-2 infection in tigers and lions at the Bronx Zoo. mBio 2020; 11 : e2220-20.

[21] Shi J, Wen Z, Zhong G, et al. Susceptibility of ferrets, cats, dogs, and other domesticated animals to SARS-coronavirus 2. Science 2020; 368: 1016-1020.

[22] Sailleau C, Dumarest M, Vanhomwegen J, et al. First detection and genome sequencing of SARS-CoV-2 in an infected cat in France. Transbound Emerg Dis. 2020; 67: 2324-2328.

[23] Mathavarajah S, Dellaire G. Lions, tigers and kittens too: ACE2 and susceptibility to COVID-19. Evol Med Public Health 2020; 2020: 109-113

[24] Abdel-Moneim AS, Abdelwhab EM. Evidence for SARS-CoV-2 infection of animal hosts. Pathogens 2020; 9: 529.

[25] Molenaar RJ, Vreman S, Hakze-van der Honing RW, et al. Clinical and pathological findings in SARS-CoV-2 disease outbreaks in farmed mink (Neovison vison). Vet Pathol. 2020; 57: 653657.

[26] Mohanty SK, Satapathy A, Naidu MM, et al. Severe acute respiratory syndrome coronavirus-2 (SARS-CoV-2) and coronavirus disease 19 (COVID-19) - anatomic pathology perspective on current knowledge. Diagn Pathol. 2020; 15: 103

[27] Oude Munnink BB, Sikkema RS, Nieuwenhuijse DF, et al. Jumping back and forth: anthropozoonotic and zoonotic transmission of SARS-CoV-2 on mink farms. bioRxiv 2020. Doi https://doi.org/10.1101/2020.09.01.277152.

[28] Morris KY, Bowman J, Schulte Hostedde A, et al. Functional genetic diversity of domestic and wild American mink (Neovison vison). Evol Appl. 2020; 13: 2610-2629

[29] Lutz C, Maher L, Lee C, et al. COVID-19 preclinical models: human angiotensin-converting enzyme 2 transgenic mice. Hum Genomics 2020; 14: 20.

[30] McCray PB Jr, Pewe L, Wohlford-Lenane C, et al. Lethal infection of K18-hACE2 mice infected with severe acute respiratory syndrome coronavirus. J Virol. 2007; 81: 813-821.

[31] Zheng J, Wong LYR, Li K, et al. COVID-19 treatments and pathogenesis including anosmia in K18-hACE2 mice. Nature 2020 Nov 9. Doi: 10.1038/s41586-020-2943-z. [Epub ahead of print]

[32] Muñoz-Fontela C, Dowling WE, Funnell SG, et al. Animal models for COVID-19. Nature 2020; 586: 509-515.
[33] Sia SF, Yan LM, Chin AW, et al. Pathogenesis and transmission of SARS-CoV-2 in golden hamsters. Nature 2020; 583: 834838.

[34] Enkirch T, von Messling V. Ferret models of viral pathogenesis. Virology 2015; 479-480: 259-270.

[35] Leist SR, Schäfer A, Martinez DR. Cell and animal models of SARS-CoV-2 pathogenesis and immunity. Dis Model Mech. 2020; 13(9): dmm046581. Doi: 10.1242/dmm.046581.

[36] Yu P, Qi F, Xu Y, et al. Age-related rhesus macaque models of COVID-19. Animal Model Exp Med. 2020; 3: 93-97.

[37] Priestnall SL. Canine respiratory coronavirus: a naturally occurring model of COVID-19? Vet Pathol. 2020; 57: 467-471.

[38] Wille M, Wensman JJ, Larsson S, et al. Evolutionary genetics of canine respiratory coronavirus and recent introduction into Swedish dogs. Infect Genet Evol. 2020; 82: 104290.

[39] Ma Z, Li P, Ji Y, et al. Cross-reactivity towards SARS-CoV-2: the potential role of low-pathogenic human coronaviruses. Lancet Microbe 2020; 1: el51.

[40] Saif LJ, Jung K. Comparative pathogenesis of bovine and porcine respiratory coronaviruses in the animal host species and SARSCoV-2 in humans. J Clin Microbiol. 2020; 58: e01355-20.

[41] Fontes D, Reyes J, Ahmed K, et al. A study of fluid dynamics and human physiology factors driving droplet dispersion from a human sneeze. Phys Fluids (1994) 2020; 32: 111904.

[42] Hartmann K. Feline infectious peritonitis. Vet Clin North Am Small Anim Pract. 2005; 35: 39-79.

[43] Kennedy MA. Feline infectious peritonitis: update on pathogenesis, diagnostics, and treatment. Vet Clin North Am Small Anim Pract. 2020; 50: 1001-1011.

[44] Addie D, Belák S, Boucraut-Baralon C, et al. Feline infectious peritonitis. $\mathrm{ABCD}$ guidelines on prevention and management. J Feline Med Surg. 2009; 11: 594-604.

[45] Pedersen NC, Perron M, Bannasch M, et al. Efficacy and safety of the nucleoside analog GS-441524 for treatment of cats with naturally occurring feline infectious peritonitis: J Feline Med Surg. 2019; 21: 271-281.

[46] Sokolowska M, Lukasik ZM, Agache I, et al. Immunology of COVID-19: mechanisms, clinical outcome, diagnostics, and perspectives - a report of the European Academy of Allergy and Clinical Immunology (EAACI). Allergy 2020; 75: 2445-2476.

[47] Beigel JH, Tomashek KM, Dodd LE, et al. Remdesivir for the treatment of COVID-19 - final report. N Engl J Med. 2020; 383: 1813-1826

[48] Balka G, Bálint Á, Cságola A, et al. Vaccine developments and pharmacological treatment options against SARS-CoV-2 infection and the control of coronaviruses in domestic animals Literature review. [A háziállatok fóbb coronavírusai, és a SARSCoV-2 elleni vakcinás és gyógyszeresvédekezés lehetôségei Irodalmi áttekintés.] Magy Állatorv L. 2020; 142: 323-348. [Hungarian]

[49] Krammer F. SARS-CoV-2 vaccines in development. Nature 2020; 586: 516-527.

[50] Saad-Roy CM, Wagner CE, Baker RE, et al. Immune life history, vaccination, and the dynamics of SARS-CoV-2 over the next 5 years. Science 2020; 370: 811-818.

(Valkó Anna dr., Budapest, Hungária krt. 23-25., 1143 e-mail: valko.anna@univet.hu)

A cikk a Creative Commons Attribution 4.0 International License (https://creativecommons.org/licenses/by/4.0/) feltételei szerint publikált Open Access közlemény, melynek szellemében a cikk bármilyen médiumban szabadon felhasználható, megosztható és újraközölhetö, feltéve, hogy az eredeti szerző és a közlés helye, illetve a CC License linkje és az esetlegesen végrehajtott módositások feltüntetésre kerülnek. (SID_1) 